\title{
共轭聚合物-氧化石墨烯钝化材料改善钙钛矿” 太阳能电池性能
}

\author{
赵大伟 ${ }^{1}$, 李铭 ${ }^{1}$, 戴世杰 ${ }^{1}$, 陈迪春 $^{2}$, 郑灵灵 ${ }^{1^{*}}$, 云大钦 ${ }^{1 *}$ \\ 1. 厦门大学能源学院, 厦门 361105 ; \\ 2. 中船重工第七二五研究所厦门材料研究院, 厦门 361006 \\ *联系人, E-mail: 1lzheng@xmu.edu.cn; dqyun@xmu.edu.cn \\ 2020-03-20 收稿, 2020-04-05 修回, 2020-04-08 接受, 2020-04-09 网络版发表 \\ 国家自然科学基金(61605164)和厦门大学能源学院发展基金(2018NYFZ05)资助
}

\begin{abstract}
摘要采用原位缩聚方法制备了新型纳米复合材料聚(2-甲氧基-5-辛氧基)-对苯乙炔-氧化石墨烯(poly[(2-methoxy,5-octoxy)1,4-phenylene vinylene]-graphene oxide, MOPPV-GO), 并将其作为钙钛矿太阳能电池(perovskite solar cells, PSCs)的超薄钝化层，大幅度提升了电池的能量转换效率(power conversion efficiency, PCE). 新型复合材料 MOPPV-GO可以充分结合两种材料的优势：GO与MOPPV复合后可在钻钛矿表面形成均匀的薄膜，有利于与空穴 传输层形成致密接触; MOPPV 以 GO 为载体聚合形成更密集的共轭网络, 显著提升电学性能. 对MOPPV-GO所制备 的器件研究表明, MOPPV-GO不仅可以有效钝化钙钛矿的表面及晶界处的缺陷, 还可以改善钙钛矿材料的结晶性, 显著提升电荷的提取与传输性能. 与标准器件相比, 修饰MOPPV-GO钝化层的器件 PCE从 $16.42 \%$ 大幅提高到 $19.73 \%$, PCE提升超过 $20.16 \%$. 该研究结果对高效稳定的PSCs的制备与研究有着很重要的价值.
\end{abstract}

关键词钝化层, MOPPV-GO, 钙钛矿太阳能电池, 界面修饰

有机-无机杂化钙钛矿太阳能电池(perovskite solar cells，PSCs)在近几年内实现了效率由 $3.8 \%$ 到 $25.2 \%$ 的 突破，被誉为有着广泛发展前景的下一代薄膜太阳能 电池 ${ }^{[1,2]}$. 然而, 电荷传输材料性能、钲钛矿晶体质量 和器件稳定性等都制约着PSCs的进一步发展 ${ }^{[3,4]}$. 经典 的PSCs有着标准的三明治结构: 电子传输层(electron transport layer, ETL)/钲钛矿层/空穴传输层(hole transport layer, HTL). 迄今为止, 为了寻找高效电荷传输材 料, 以进一步提升PSCs的能量转换效率(power conversion efficiency, PCE), 研究人员探索了大量的有机和无 机材料, 以寻求具有合适能级和高电荷迁移率的电荷 传输材料 ${ }^{[5]}$. 另外, 为了改善钙钛矿太阳能电池器件 的电荷传输性能, 设计和优化电荷传输材料/钙钛矿的
界面是一个基本要求. 选择合适的界面工程设计是显 著提升钙钛矿电池性能的重要方法之一, 可以有效地 钝化钙钛矿表面和晶界处的缺陷, 大幅度改善电荷提 取和传输效率, 整体提升器件的性能 ${ }^{[8 ~ 11]}$. 研究表明, 钝化层是一种有效的界面工程, 它在PSCs的器件性能 方面起着至关重要的作用 ${ }^{[12,13]}$. Peng等人 ${ }^{[14]}$ 将高分子/ 富勒烯薄膜材料作为PSCs的超薄钝化层, 发现该材料 能够有效钝化钙钛矿与电子传输材料之间的缺陷, 抑 制界面复合，不仅提升了PSCs的开路电压至 $1.18 \mathrm{~V}$, 而 且抑制了器件的回滞现象, 使器件输出效率更加稳定.

近年来, 氧化石墨烯(graphene oxide, GO) 由于其卓 越的特性, 如出色的物理和化学稳定性、超高功函数 和高透过性而备受关注 ${ }^{[15 ~ 19]}$, 在光伏领域具有众多潜 
在的应用. 例如, $\mathrm{Li}$ 等人 ${ }^{[20]}$ 用 $\mathrm{GO}$ 来钝化修饰钙钛矿/ HTL的界面, 将PSCs的器件效率从 $10.0 \%$ 提升到 $14.5 \%$. 这是由于 $\mathrm{GO}$ 与钙钛矿活性层中的 $\mathrm{Pb}$ 原子形成了化学 键, 能够减少未完全形成配位的 $\mathrm{Pb}$ 原子数量, 降低了缺 陷态密度, 提高了电池性能. 然而, 高含氧量的 GO具有 相对较低的导电性能; 同时, 不均匀的 GO纳米片很难 在钙钛矿表面形成均匀连续的膜, 也很难与HTL形成 紧密接触, 这些特点均限制了 GO材料在太阳能电池方 面的发展空间. GO材料因具有大的比表面积 ${ }^{[16]}$, 成为 可用于生长和针定功能化高分子的石墨烯基复合材料 理想的前驱体或基材.

最近, 为了更好地挖掘 $\mathrm{GO}$ 材料在PSCs方面的应用 潜能, 研究人员将其他性能优异的材料与 $\mathrm{GO}$ 纳米片进 行复合以产生协同作用, 共同提升PSCs的光伏性能. 例 如, Mann等人 ${ }^{[21]}$ 报告了基于PEDOT:PSS(poly(3,4-ethylenedioxythiophene):poly(styrene sulfonate))/硫化还原 GO的双重HTL对PSCs器件性能和稳定性的影响. 硫酸 功能化的还原GO的引人, 使这种双重HTL具备更高的 功函数和电导率, 显著提升了电荷传输能力. Lee等 人 $^{[22]}$ 在 2016 年提出将PEDOT:PSS/GO复合材料作为 HTL来构建高效稳定的PSCs 器件. 由于GO具有较大的 带隙, 能有效阻挡电子传输. 另外, PEDOT:PSS与GO有 良好的能级匹配, 能显著降低器件的串联电阻.

为了更好地结合两种材料的优点, 本文采用原位 缩聚方法制备了新型纳米复合材料聚(2-甲氧基-5-辛 氧基)-对苯乙炔-氧化石墨烯(poly[(2-methoxy,5-octoxy) 1,4-phenylenevinylene]-graphene oxide, MOPPV-GO), 并将其引人钙钛矿层和HTL之间, 作为PSCs的超薄钝 化层. MOPPV的HOMO能级 $(-5.1 \mathrm{eV})$ 能与 GO很好地 匹配, 该界面材料的引人, 可以有效抑制电荷在界面的 复合, 改善回滞现象.

\section{1 实验部分}

\section{1 原料}

(i ) 钻钛矿原料及合成. 本文所使用的双三氟甲 烷磺酰亚胺锂盐(Li-TFSI，99.95\%)、4-叔丁基吡啶(4tBP，96\%)、无水二甲基甲酰胺(DMF，99.8\%)、甲胺 盐酸盐 $(\mathrm{MACl})$ 、异丙醇钛 $(\mathrm{IV})(\mathrm{TTIP}, 97 \%)$ 、乙酸甲脒 盐 $(99 \%)$ 、氢碘酸 $(\mathrm{HI}, 57 \mathrm{wt} \%)$ 、无水二甲基亚砜 (DMSO, 99.9\%)、乙腈(99.8\%)和氯苯(99.8\%)均由Sigma-Aldrich公司提供. Spiro-OMeTAD购自Ossila公司.
钴配合物(FK209)购自Dyenanmo公司. 碘化铅( II) (99.999\%)由Alfa-Aesar公司提供. 其中, spiro-OMe$\mathrm{TAD}$ 根据文献[23]制备, 需先将其溶解在一定量的氯苯 中 $\left(60 \mathrm{mmol} \mathrm{L}^{-1}\right)$, 然后依次加人 Li-TFSI $\left(30 \mathrm{mmol} \mathrm{L}^{-1}\right)$ 、 4-tBP(200 $\left.\mathrm{mmol} \mathrm{L}^{-1}\right)$ 和FK209(1.8 $\left.\mathrm{mmol} \mathrm{L}^{-1}\right)$. $\mathrm{PbI}_{2}$ (DMSO)溶液和甲脒磑(FAI)均按照文献[24]制备, 使用 前需在 $70^{\circ} \mathrm{C}$ 下加热搅拌. $\mathrm{TiO}_{2}$ 纳米颗粒根据文献[24]报 道的异丙醇钛水解方法制备. 未经特殊说明, 所有材料 在使用前均未被进一步提纯.

(ii) 单体合成. 前驱体1,4-双(氯甲基)-2-甲氧基-5辛氧基-苯按照我们先前研究中描述的方法制备 ${ }^{[25]}$. 首 先, 在乙醇钠条件下, 由4-甲氧基苯酚与正辛基溴反应 合成1-甲氧基-4-辛氧基-苯. 然后, 通过在甲醛、 $\mathrm{HCl}$ 和 少量低聚甲醛的二恶烷溶液中对其前体进行氯甲基化, 制备单体1,4双(氯甲基)-2-甲氧基-5-辛氧基-苯. GO纳 米片是根据文献[26], 通过直流电弧放电法制备, 使用 前从二苯甲酮钠中蒸馏出四氢呋喃(THF). 除非另有说 明, 其他化学药品均购自Alderich Chemical Co, 所有材 料在使用前均未被进一步提纯.

(iii) MOPPV-GO复合材料合成. 首先, 向圆底烧瓶 中用氮气充分冲洗并在机械搅拌下装上变阻器, 在 $70^{\circ} \mathrm{C}$ 的干燥 THR中加人叔丁醇钾溶液. 然后, 用注射葲 以 $20 \mathrm{~mL} / \mathrm{h}$ 的速率加人单体, 即 1,4 -双(氯甲基)-2-甲氧 基-5-辛氧基-苯和几层石墨烯在无水 THF中的混合溶 液. 加完后, 将反应下的共混溶液摚拌 $12 \mathrm{~h}$. 将反应产物 倒人快速搅拌的甲醇中, 并通过抽滤收集沉积物. 最后, 用甲醇: 水混合物(10:1, 体积:体积)洗涤3次, 以除去副 产物, 在真空下干燥后备用.

\section{2 器件制备}

（i） ITO导电玻璃清洗. 本文所用氧化铟锡(ITO) 在使用前需要充分清洁干净, 以保证涂膜质量. 清洗 时, 首先需要将已经刻蚀完成的ITO使用洗洁精搓洗干 净, 紧接着依次使用ITO洗涤剂、去离子水、乙醇和异 丙醇溶剂在超声机中分别清洗 $20 \mathrm{~min}$. 其中, 在使用洗 洁精和ITO洗涤剂时, 需保持水温 $90^{\circ} \mathrm{C}$, 再将 ITO基底 用气枪吹干, 然后经紫外臭氧机清洗 $15 \mathrm{~min}$, 备用.

(ii) ETL的制备. 本文的器件主体是基于溶液旋涂 法在匀胶机上制备完成的. 首先, 在已经清洁干净的 $\mathrm{ITO}$ 导电玻璃上, 用移液枪取适量 $20 \mathrm{mg} \mathrm{mL}^{-1}$ 的 $\mathrm{TiO}_{2}$ 溶 液以 $4000 \mathrm{r} / \mathrm{min}$ 在基底上旋涂 $60 \mathrm{~s}$. 旋涂结束后, 在大气 环境下将 $\mathrm{TiO}_{2}$ 薄膜放置热台上 $120^{\circ} \mathrm{C}$ 退火 $60 \mathrm{~min}$. 冷却 
至室温后, 将涂覆 $\mathrm{TiO}_{2}$ 薄膜的ITO基底转移至处于氩气 保护的手套箱内, 等待下一步使用.

(iii) 钙钛矿层与钝化层的制备. 首先, 为了探索不 同浓度MOPPV-GO对器件的影响，对MOPPV-GO溶液 设置了一个浓度梯度，即 $0.25 、 0.5$ 和 $1 \mathrm{mg} \mathrm{mL}^{-1}$. 在处 于氩气保护的手套箱内，用移液枪取适量 $1.50 \mathrm{~mol} / \mathrm{L}$ 的 $\mathrm{PbI}_{2}(\mathrm{DMSO})$ 前驱体溶液以 $2500 \mathrm{r} / \mathrm{min}$ 在涂覆 $\mathrm{TiO}_{2}$ 薄 膜表面上滴加并旋涂。随后，换用新移液枪取适量 $70 \mathrm{mg} \mathrm{mL}^{-1}$ 的FAI和MACl的混合异丙醇溶液，以 $2500 \mathrm{r} / \mathrm{min}$ 旋涂在 $\mathrm{PbI}_{2}(\mathrm{DMSO})$ 薄膜表面上．然后，以 $2500 \mathrm{r} / \mathrm{min}$ 旋涂MOPPV-GO溶液. 在 $120^{\circ} \mathrm{C}$ 的热台退火, 形成钙钛矿薄膜/钝化层, 退火结束后冷却至室温.

(iv) HTL的制备. 使用移液枪取适量配好的spiroOMeTAD溶液以 $2000 \mathrm{r} / \mathrm{min}$ 在沉积钙钛矿层/修饰层顶 部旋涂 $50 \mathrm{~s}$, 制备HTL层.

（V）高真空蒸发金属Ag电极. 将制备好的器件储 存在干燥柜中, 经过 $24 \mathrm{~h}$ 的干燥氧化后, 在 $10^{-4} \mathrm{~Pa}$ 的真 空条件下，使用高真空热蒸发镀膜仪器蒸镀 $100 \mathrm{~nm}$ 金 属银电极. 为确定电池的有效面积为 $0.1 \mathrm{~cm}^{2}$, 需要在电 池上方覆盖掩模版. 同时, 未修饰MOPPV-GO的参比电 池样品在相同条件下制备.

\section{3 表征方法}

采用透射电子显微镜(transmission electron microscopy，TEM)对 GO纳米片及MOPPV-GO纳米复合材料 的形貌进行分析, 需将 $\mathrm{GO}$ 溶液及MOPPV-GO溶液滴加 在铜网上并干燥后转移至TEM测试仓进行测试，以获 得高分辨率的TEM图像. 采用扫描电子显微镜( scanning electron microscopy, SEM)和原子力显微镜(atomic force microscopy, AFM) 对钲钛矿薄膜的微观形貌进行 表征. 待测样品的吸收光谱通过紫外-可见吸收光谱仪 (ultraviolet-visible absorption spectrometry, UV-Vis)测 得。光电流密度-电压 $(J-V)$ 性能测试在光强为 $100 \mathrm{~mW} \mathrm{~cm}{ }^{-2}$ 的AM $1.5 \mathrm{G}$ 的模拟太阳光下通过Keithley 2420测试系统进行测量, 使用前已经使用 $\mathrm{Si}$ 标准电池 校准. 除非另有说明，否则均以 $20 \mathrm{mV} / \mathrm{s}$ 扫描速度和 $-0.1 \sim 1.2 \mathrm{~V}$ 扫描电压范围分别在反向扫描(reverse scan direction, RS, from open circuit to short circuit)和正向扫 描(forward scan direction, FS, from short circuit to open circuit)下测量 $J-V$ 特性曲线. 为了进一步量化基于不同 ETL结构的PSCs的回滞效应，根据以下公式计算回滞 系数(hysteresis index, $\mathrm{HI}): \mathrm{HI}=\left(J_{\mathrm{RS}}\left(0.8 \times V_{\mathrm{OC}}\right)-J_{\mathrm{FS}}(0.8 \times\right.$
$\left.\left.V_{\mathrm{OC}}\right)\right) / J_{\mathrm{RS}}\left(0.8 \times V_{\mathrm{OC}}\right)^{[27]}$. 同时, 采用 $\mathrm{X}$ 射线衍射(X-ray diffraction, XRD) 对钙钛矿薄膜的晶体结构性质进行表征. 器件的外量子效率(external quantum efficiency, EQE)通 过使用Newport太阳能电池光谱响应测量系统进行测 量. 为了研究器件内部的电学性质, 通过VersaSTAT3化 学工作站(Princeton Applied Research)进行测试并绘制 相应的电化学阻抗谱(electrochemical impedance spectroscopy, EIS).

\section{2 结果与讨论}

\subsection{MOPPV-GO纳米复合材料表征}

图 1 给出了直径约为 $170 \mathrm{~nm}$ 的 $\mathrm{GO}$ 纳米片和 MOPPV-GO纳米复合物的TEM图像. 对比发现, 在共轭 聚合物MOPPV包裹 GO纳米片后，会造成其表面相对 模糊，而未包裹共轭聚合物 MOPPV的 GO纳米片的 TEM图像十分清晰，表明功能性聚合物MOPPV已经成 功地针定在石墨烯纳米片中.

\section{2 钙钛矿薄膜表征}

将上述新型MOPPV-GO纳米复合材料作为超薄钝 化层，修饰钙钛矿层与HTL的界面制备n-i-p平面PSC, 器件结构为 $\mathrm{ITO} / \mathrm{TiO}_{2} /\left(\mathrm{FAPbI}_{3}\right)_{x}\left(\mathrm{MAPbCl}_{3}\right)_{1-x} / \mathrm{MOPPV}-$ $\mathrm{GO} / \mathrm{Spiro}-\mathrm{OMeTAD} / \mathrm{Ag}$. 图2(a)和(b)分别为修饰 MOPPV-GO的PSCs结构示意图和相应的SEM截面形 貌图．如图2(c) (f)所示，通过AFM下的高度图和SEM 的表面形貌图细致观察了MOPPV-GO复合物对钻钛矿 薄膜形貌的影响, 并将这些结果与光伏性能关联. 通过 对比发现，修饰与未修饰MOPPV-GO钝化层的钻钛矿 表面形貌有明显差异．修饰MOPPV-GO的钻钛矿薄膜 更加致密、平整，并且均匀分布着微米级别的高质量

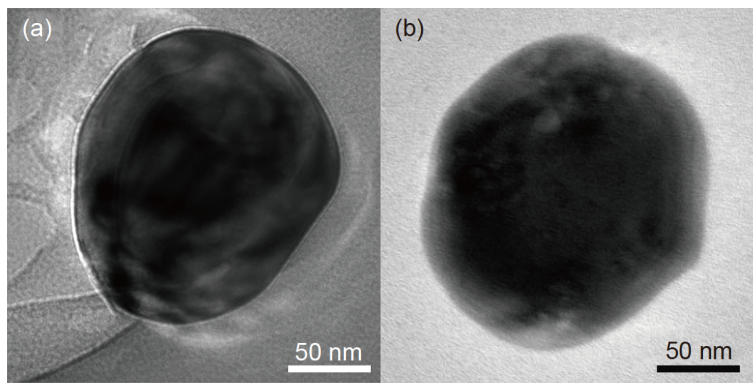

图 1 TEM图. (a) GO纳米片; (b) MOPPV-GO纳米复合物 Figure 1 TEM images. (a) GO nanosheet; (b) MOPPV-GO nanocomposite 


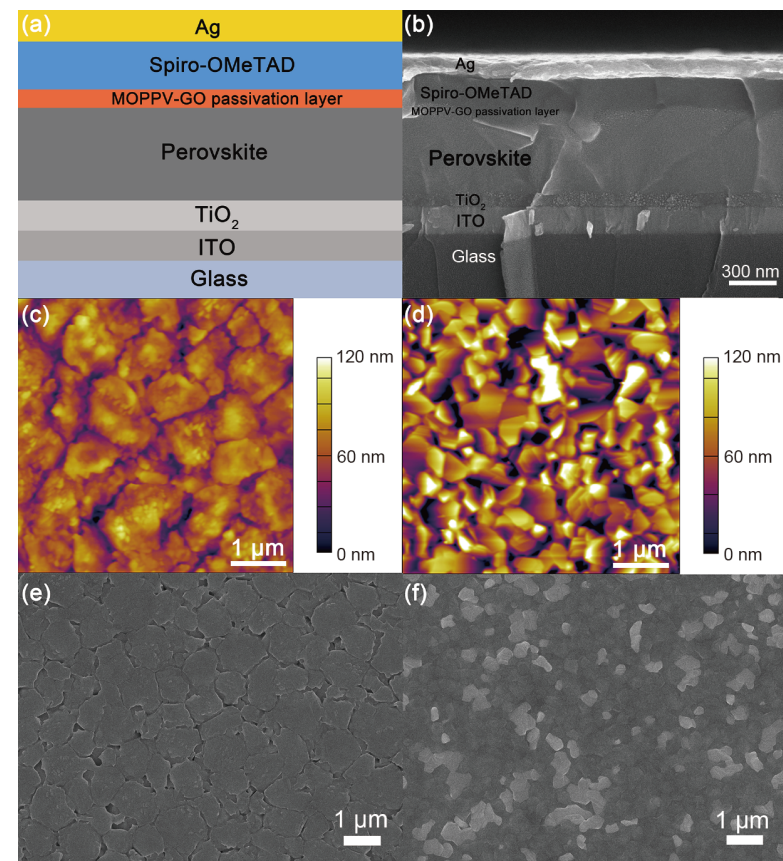

图 2 (网络版彩色) 器件结构与薄膜形貌. (a) 修饰MOPPV-GO的 PSCs结构示意图; (b) 修饰MOPPV-GO的PSCs的SEM截面图; (c) 修 饰MOPPV-GO的钙钛矿薄膜的AFM形貌图; (d) 未修饰MOPPV-GO 的钙钛矿薄膜的AFM形貌图; (e) 修饰MOPPV-GO的钙钛矿薄膜的 SEM表面形貌图; (f) 未修饰MOPPV-GO的钻钛矿薄膜的SEM表面 形貌图

Figure 2 (Color online) Structure of the device and morphology of the film. (a) Schematics of PSCs architectures with MOPPV-GO; (b) crosssectional SEM image of PSCs with MOPPV-GO; AFM topography images of perovskite films with (c) and without (d) MOPPV-GO; topview SEM images of perovskite films with (e) and without (f) MOPPVGO

钙钛矿晶粒. 相反, 未修饰的钙钛矿薄膜晶粒较小，且 大小不均一. 修饰MOPPV-GO的钻钛矿薄膜的均方根 粗䊁度(root mean square roughness, RMS) 为 $19.87 \mathrm{~nm}$,
小于未修饰的钻钛矿薄膜的 $25.85 \mathrm{~nm}$. 该实验结果进一 步证明, 修饰MOPPV-GO可以改善钲钛矿表面形貌, 与 HTL形成更紧密的接触，从而减小界面处的电荷损失. 事实上，许多研究报道己经证实，制备性能优异的 PSCs的前提是获得大晶粒尺寸、致密和结晶良好的钙 钛矿薄膜. 这是因为晶粒更大的钲钛矿薄膜有着较低 的晶界密度，可以有效地减少器件中晶界处的电荷复 合 ${ }^{[28]}$. 因此, 制备高质量的钙钛矿薄膜可以大幅度提高 器件的光伏性能.

为了进一步研究MOPPV-GO复合材料对钙钛矿结 晶度的影响, 对钻钛矿薄膜进行了相应的光学性能和 结构表征. 在PSCs器件中, 钙钛矿薄膜的吸光能力越 强, 其器件就越能更加有效地进行光电转换, 而在同等 厚度下，结晶和成膜质量决定了钙钛矿薄膜的吸光性 能. 首先，图3(a)显示了经过修饰和未经修饰的钻针矿 薄膜的 UV-Vis吸收光谱. 可以看出, 在整个450 850 nm 波长区间内，经MOPPV-GO修饰的钻钛矿薄膜的吸收 系数均高于未修饰的, 表现出更优越的吸光性能. 因 此，修饰后的钙钛矿活性层可以实现更多的光子收集， 实现更高的光电流. 同时, 在相同条件下测量了修饰有 不同浓度MOPPV-GO的钲钛矿薄膜的XRD衍射图谱. 如图3(b)所示, 修饰和未修饰MOPPV-GO的钙钛矿薄膜 的XRD图谱中的衍射峰位置基本一致，主要特征峰位 于 $14.2^{\circ}(110)$ 和 $28.3^{\circ}(220)$, 但与未修饰MOPPV-GO 的样品相比, 修饰MOPPV-GO的钙钛矿薄膜样品均表 现出了更高且尖锐的特征峰, 尤其当修饰 $0.5 \mathrm{mg} \mathrm{mL}^{-1}$ 的MOPPV-GO时, 钙钛矿样品的衍射峰强度最大. 结果 表明，该钝化层可以显著增强钻钛矿薄膜的结晶程度， 获得更高质量的钙钛矿薄膜. 钙钛矿薄膜的生长受很
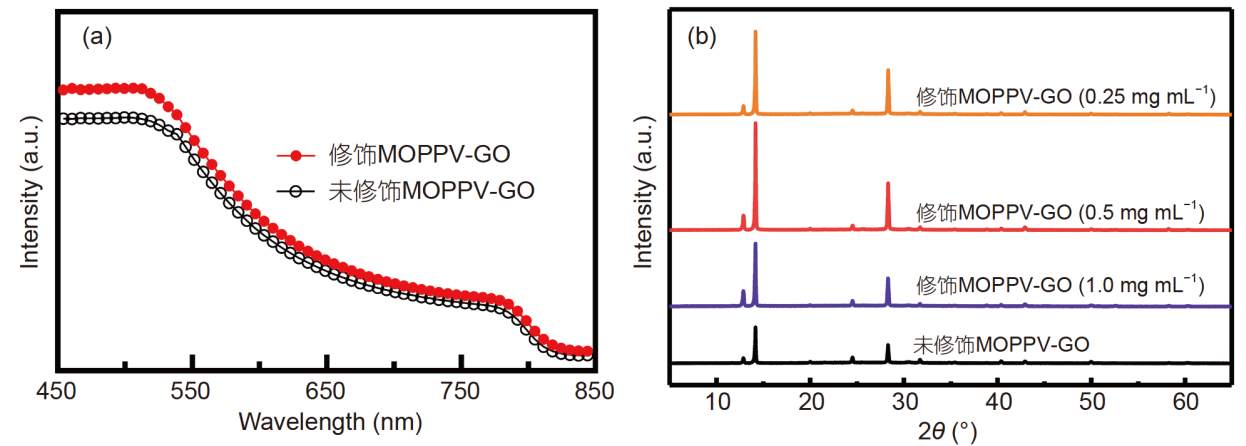

图 3 (网络版彩色)UV-Vis吸收光谱图和XRD图谱. (a) 修饰和未修饰MOPPV-GO的钙钛矿薄膜的UV-Vis吸收光谱图; (b) 修饰不同浓度 MOPPV-GO的钲钛矿薄膜的XRD图谱

Figure 3 (Color online) UV-Vis absorption spectra and XRD patterns. (a) UV-Vis absorption spectra of the perovskite films with and without MOPPV-GO; (b) XRD patterns of perovskite films with MOPPV-GO of different concentrations 
多因素的影响, 如生长基底的浸润性和表面形貌，由于 本文中钙钛矿薄膜是在相同基底上生长的，因此钲钛 矿薄膜的质量主要受MOPPV-GO钝化层的影响. 可以 推测, 在钙钛矿晶体的生长过程中, MOPPV-GO的存在 可能诱导了部分表面的钙钛矿晶粒朝着均一的方向生 长, 使其结晶性能获得提升. 当未修饰或MOPPV-GO很 低浓度修饰时, 该效应未能充分显现; 而当MOPPV-GO 的浓度较大时，由于疏水性共轭高分子MOPPV与亲水 的钙钛矿基底不浸润，使修饰材料与钙钛矿之间的亲 和性变差, 此外 GO纳米片本身比较粗粘, 也会对钙钛 矿薄膜的质量产生不利影响.

\section{3 器件光伏性能}

为了进一步研究MOPPV-GO复合物对钙钛矿器件 性能的影响，进行了一系列光伏性能测试. 表1是基于 不同浓度MOPPV-GO的PSCs的光伏参数统计. 结果显 示, 修饰有 $0.5 \mathrm{mg} \mathrm{mL}^{-1}$ MOPPV-GO的PSCs 表现出了最 佳的光伏性能. 如果不特殊注明, 均采用此最佳浓度的 MOPPV-GO来制备修饰的PSCs. 图4(a)和插图是修饰 和未修饰MOPPV-GO的PSCs的 $J-V$ 特性曲线和详细光 伏参数. 可以看出, 修饰了MOPPV-GO的PSCs的开路电 压(open circuit voltage, $V_{\mathrm{OC}}$ )、短路电流(short circuit current, $J_{\mathrm{SC}}$ )、填充因子(fill factor, $\mathrm{FF}$ ) 和能量转换效率 (power conversion efficiency, PCE)分别为 $1.09 \mathrm{~V}$ 、 $23.54 \mathrm{~mA} \mathrm{~cm}^{-2} 、 76.46 \%$ 和 $19.73 \%$, 与未修饰MOPPV$\mathrm{GO}$ 的 P SCs 的光伏性能 ( $V_{\mathrm{OC}}$ 为 $1.07 \mathrm{~V}, J_{\mathrm{SC}}$ 为 $22.73 \mathrm{~mA} \mathrm{~cm}^{-2}, \mathrm{FF}$ 为 $67.77 \%$, PCE为 $16.42 \%$ )相比有较 大改善, PCE提升了 $20.16 \%$. 此外, 我们发现修饰了 MOPPV-GO的PSCs, 采用不同扫描方向进行测量, 其 $J$ $V$ 特性曲线几乎重合，反向扫描时PCE为 $19.73 \%$, 正向 扫描时PCE为 $19.39 \%$ ，下降了仅仅 $0.34 \%$ ，此时的回滞 系数为 0.02 ; 而未修饰MOPPV-GO的PSC反向扫描时 PCE为 $16.42 \%$, 正向扫描时PCE为 $13.39 \%$, 下降了
$2.93 \%$, 对应的回滞系数为 0.18 . 这可能是由于修饰 MOPPV-GO后, 钙钛矿层质量改善, 减少了钙钛矿层的 缺陷态密度, 器件内部的回滞效应被充分地抑制. 与此 同时，还测量了PSCs的外量子效率(external quantum efficiency, EQE), 以进一步证明实验所得 $J_{\mathrm{SC}}$ 数据的准 确性，测试结果如图4(b)所示. 可以看出，在整个测试 波长范围内, MOPPV-GO修饰的PSC的EQE曲线均高 于未修饰MOPPV-GO的PSC的EQE曲线，相对应的积 分电流密度分别为 22.80 和 $21.04 \mathrm{~mA} \mathrm{~cm}^{-2}$, 与 $J-V$ 曲线 的 $J_{\mathrm{SC}}$ 数据保持一致. 为了验证实验结果的可重复性与 可靠性，在相同工艺条件下，分别制备了50个修饰 MOPPV-GO的PSCs和未修饰MOPPV-GO的PSCs, 对其 进行 $J-V$ 特性曲线测试并统计其主要光伏参数(图4(c)). 通过对比可以发现, 加人MOPPV-GO钝化层后, 电池的 主要光伏参数都有所上升, 尤其是 $J_{\mathrm{SC}}$ 与 $V_{\mathrm{OC}}$ 数值都得到 了显著提升. 结果表明, 加人MOPPV-GO钝化层后，可 以有效发挥两种材料的协同作用: $\mathrm{GO}$ 纳米片具有较高 的功函数, 意味着其可以与钲钛矿活性层形成欧姆接 触, 得到更高的 $V_{\mathrm{OC}}$; 而 $\mathrm{GO}$ 纳米片与共轭聚合物 MOPPV原位复合后, 改善了GO纳米片的成膜性, 使其 可以在钙钛矿表面较好地成膜，钝化了钙钛矿薄膜表 面和晶界处的缺陷, 减少载流子在表界面的复合, 大幅 度提升了 $\mathrm{FF}$ 和 $J_{\mathrm{SC}}$.

为了深人研究MOPPV-GO的修饰对PSCs电学性 能的作用, 采取EIS图谱来表征钙钛矿/HTL界面处的 电荷动力学. 如图4(d)所示, 在黑暗条件下, 对修饰和 未修饰MOPPV-GO的PSCs施加 $0.2 \mathrm{~V}$ 直流偏压和 $20 \mathrm{~mA}$ 电流, 在 $1 \mathrm{MHz} 0.1 \mathrm{~Hz}$ 范围内进行测试并统计 数据. 测试得到的奈奎斯特图谱有两个特征: 高频半圆 弧与电荷迁移动力学相关, 可以得到器件内部的串联 电阻与转移电阻信息, 即高频半圆弧直径越小, 则相应 器件电荷迁移阻力越小, 电荷传输效率越高; 低频半圆 弧则关联电荷复合动力学, 可以获得器件复合电阻数

表 1 基于不同浓度MOPPV-GO的PSCs的光伏参数统计

Table 1 Photovoltaic parameters of PSCs based on different concentration MOPPV-GO

\begin{tabular}{|c|c|c|c|c|c|}
\hline 样品名称 & 扫描方向 & $V_{\mathrm{OC}}(\mathrm{V})$ & $J_{\mathrm{SC}}\left(\mathrm{mA} \mathrm{cm}^{-2}\right)$ & $\mathrm{FF}(\%)$ & $\operatorname{PCE}(\%)$ \\
\hline 未修饰MOPPV-GO & $\mathrm{R}$ (champion) & 1.07 & 22.73 & 67.77 & 16.42 \\
\hline 修饰0.25 mg mL ${ }^{-1}$ MOPPV-GO & $\mathrm{R}$ (champion) & 1.07 & 23.10 & 76.85 & 18.96 \\
\hline 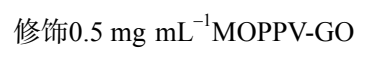 & $\mathrm{R}$ (champion) & 1.09 & 23.54 & 76.46 & 19.73 \\
\hline 修饰1.0 mg mL ${ }^{-1} \mathrm{MOPPV-GO}$ & $\mathrm{R}$ (champion) & 1.08 & 23.72 & 74.42 & 19.11 \\
\hline
\end{tabular}



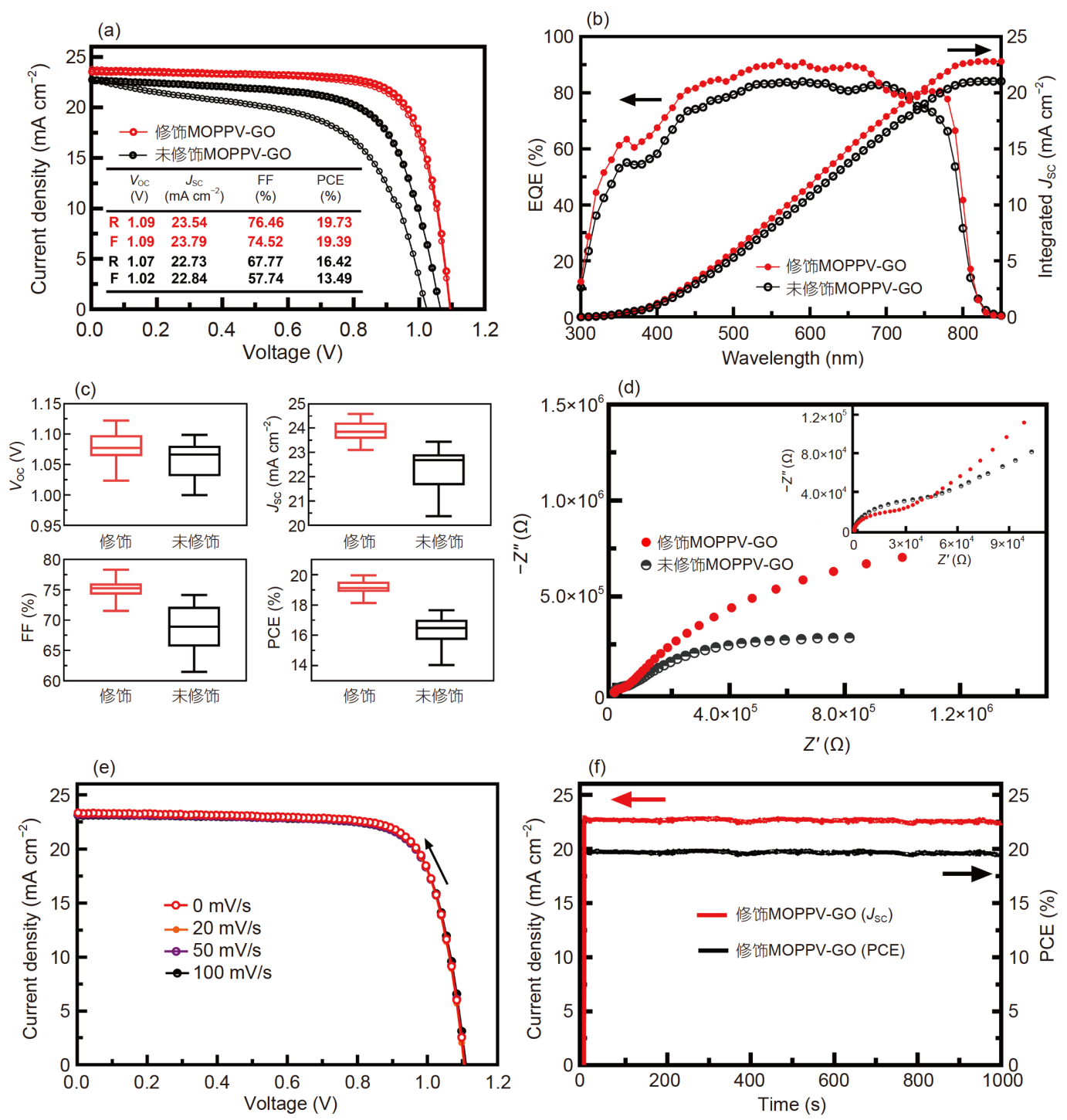

图 4 (网络版彩色)光伏性能. (a) 修饰和未修饰MOPPV-GO的PSCs的正向/反向扫描 $J-V$ 曲线; (b) 修饰和未修饰MOPPV-GO的PSCs的EQE和积 分电流图谱; (c) 修饰和未修饰MOPPV-GO的PSCs在反向扫描下光伏参数统计; (d) 0.2 V偏压下，于黑暗条件下测得修饰和未修饰MOPPV的 PSCs的奈奎斯特图, 插图为高频放大图谱; (e) 修饰和未修饰MOPPV-GO的PSCs在反向扫描下不同扫速的 $J-V$ 曲线; (f) $0.87 \mathrm{~V}$ 偏压下, 修饰和未 修饰MOPPV-GO的PSCs稳定输出的PCE和 $J_{\mathrm{SC}}$

Figure 4 (Color online) Photovoltaic performance. (a) The champion $J-V$ curves of the PSCs with and without MOPPV-GO; (b) EQE plots and the integrated current density of the PSCs with and without MOPPV-GO; (c) statistical data for photovoltaic parameters of the PSCs with and without MOPPV-GO in the reverse scanning direction; (d) Nyquist plots of the PSCs with and without MOPPV-GO in dark at $0.2 \mathrm{~V}$; the inset is a zoom-in of the high-frequency region; (e) $J$ - $V$ curves of the PSCs with and without MOPPV-GO measured at various delay time in the reverse scanning direction; (f) stabilized PCE and $J_{\text {SC }}$ of the PSCs with MOPPV-GO measured at $0.87 \mathrm{~V}$ bias

据，即低频半圆弧直径越大，则器件复合电阻越大，器 件的电荷复合过程越少. 器件的差异仅为超薄钝化层 的引人带来的改变, 因此通过比较半圆弧直径的大小, 可以研究器件的电荷迁移与复合情况 ${ }^{[29]}$. 将修饰与未 修饰MOPPV-GO的PSCs的EIS曲线比较分析可以知道, 修饰MOPPV-GO的PSCs具有较小的串联电阻, 同时具 有较大的复合电阻, 即MOPPV-GO可以在钙钛矿/HTL
界面处发挥出优异的界面效应，改善钻钛矿/HTL界面 接触, 减小因界面处的电荷复合带来的能量损失, 同时 提高器件的 FF和 $V$ oc. 为了进一步研究修饰MOPPVGO对器件回滞效应的影响, 在保证其他测量参数一致 的情况下, 通过改变测试扫速, 绘制了一系列不同扫速 的 $J-V$ 特性曲线(图4(e)). 通过对比, 我们发现在不同扫 速下的 $J-V$ 特性曲线差别很小以至可以忽略, 有较好的 
重合性，表明修饰MOPPV-GO的器件的回滞效应能够 被有效地抑制，从而使 $J-V$ 特性曲线有着较好的输出一 致性. 这是由于修饰MOPPV-GO钝化材料后, 可以获得 晶粒更大且均匀的高质量钲钛矿薄膜，即薄膜中的晶 界与缺陷的密度更低，从而抑制了器件的回滞效应 ${ }^{[26]}$; 同时，MOPPV-GO的修饰有效改善了钙钛矿/HTL之间 的界面, 减少了电荷复合, 其HOMO能级也与钙钛矿材 料 $(-5.4 \mathrm{eV})$ 有着良好的匹配, 电荷传输更为有效, 器件 的响应速度加快 ${ }^{[30,31]}$. 我们知道, 对于太阳能电池, 不 仅仅需要获得高的能量转换效率，还需要能够长时间 稳定工作, 因此采用在最大功率点(maximum power point, MPP)测试修饰MOPPV-GO的PSCs的PCE的输出 稳定性. 如图4(f)所示, 在光强为 $100 \mathrm{~mW} \mathrm{~cm}$ 的 $\mathrm{AM}$ $1.5 \mathrm{G}$ 的模拟太阳光下，对未封装的器件施加 $0.87 \mathrm{~V}$ 偏 压, 并连续1000 s模拟太阳光照射, 记录电池的电流密 度输出值. 可以看出, 修饰MOPPV-GO的器件能够在光 照起始就迅速达到电流密度输出高点, 说明钝化材料 可以有效提升器件内部界面处的电荷传输, 即能更快 地响应产生光生电流. 此外, 器件在经过 $1000 \mathrm{~s}$ 连续光 照后，其电流密度输出值没有发生太大变化，约为 $22.41 \mathrm{~mA} \mathrm{~cm}^{-2}$, 其相应的稳态 $\mathrm{PCE}$ 为 $19.50 \%$, 与 $J-V$ 测 试中的 PCE数值保持高度一致性. 结果表明，修饰 MOPPV-GO的PSCs不仅有着更优异的电荷传输性能, 而且能够一直保持较高的光捕获能力, 从而维持长时 间的功率输出稳定性. 可以预期，修饰MOPPV-GO的 PSCs在自然环境下，即使在未封装的情况下，也能保 持长期工作的能力.

为了研究修饰MOPPV-GO对器件稳定性的影响, 在室温和湿度为 $20 \%$ 30\%的条件下，对未封装的器件 进行约 $1000 \mathrm{~h}$ 的稳定性监测，结果如图5所示. 可以看 出, 经过 $1000 \mathrm{~h}$ 的测试后, 未修饰MOPPV-GO的器件效

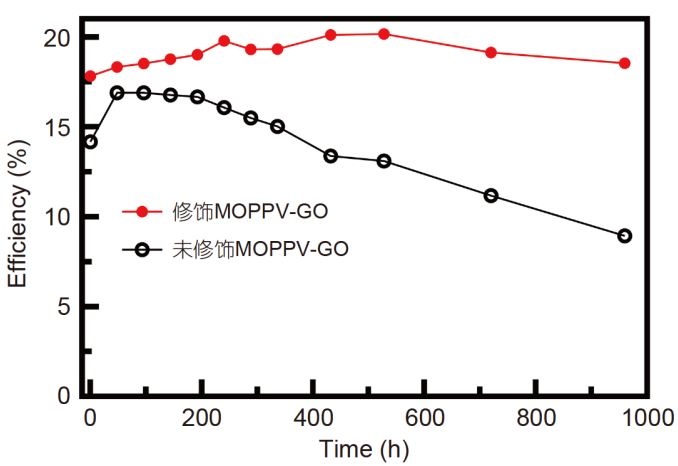

图 5 (网络版彩色)修饰和未修饰MOPPV-GO的未封装PSCs的PCE 衰减变化

Figure 5 (Color online) PCE decay of unpackaged PSCs with and without MOPPV-GO

率已衰减至原来的 $53 \%$ ，但修饰MOPPV-GO的器件效 率仍然保持原来的 $92 \%$ 以上，显示出了优异的工作稳 定性．稳定性的提升来源于MOPPV-GO复合物本身的 疏水性，可在钲钛矿表面及晶界处形成疏水屏障, 隔绝 外界水汽对钙钛矿薄膜的破坏.

\section{3 总结}

本文采用原位缩聚的方法成功将 $\mathrm{GO}$ 纳米片和共轭 聚合物MOPPV结合, 作为钙钛矿太阳能电池中钲钛矿/ HTL界面的钝化层. 新型MOPPV-GO可在钙钛矿表面 形成均匀的薄膜, 从而与HTL形成紧密接触; MOPPV 以 $\mathrm{GO}$ 为载体聚合形成更密集的共轭网络, 能够针化钲 钛矿的表界面及晶界处的缺陷，显著提升了电荷的提 取与传输性能. 与未修饰器件相比, 修饰MOPPV-GO钝 化层的器件能量转换效率从 $16.42 \%$ 大幅提高到 $19.73 \%$, 效率增长了 $20.16 \%$, 同时表现出优异的输出功率稳定 性. 综上所述，该工作可以为石墨烯基复合材料的合成 及其在太阳能电池领域中的应用开辟新的思路.

\section{参考文献}

1 Kojima A, Teshima K, Shirai Y, et al. Organometal halide perovskites as visible-light sensitizers for photovoltaic cells. J Am Chem Soc, 2009, 131: $6050-6051$

2 Baktash A, Amiri O, Saadat M. High efficient perovskite solar cells base on Niobium doped $\mathrm{TiO}_{2}$ as a buffer layer. J Nanostruct, 2020, 10: 119-127

3 Wang D, Wright M, Elumalai N K, et al. Stability of perovskite solar cells. Sol Energy Mater Sol Cells, 2016, 147: 255-275

4 Wang D, Zhang L, Deng K, et al. Influence of polymer additives on the efficiency and stability of ambient-air solution-processed planar perovskite solar cells. Energy Technol, 2018, 6: 2380-2386

5 Wang Y, Yue Y, Yang X, et al. Toward long-term stable and highly efficient perovskite solar cells via effective charge transporting materials. Adv Energ Mater, 2018, 8: 25

6 Wang Y, Hu Y, Han D, et al. Ammonia-treated graphene oxide and PEDOT:PSS as hole transport layer for high-performance perovskite solar cells with enhanced stability. Org Electron, 2019, 70: 63-70 
7 Arora N, Dar M I, Hinderhofer A, et al. Perovskite solar cells with CuSCN hole extraction layers yield stabilized efficiencies greater than 20\%. Science, 2017, 358: 768-771

8 Chueh C C, Li C Z, Jen A K Y. Recent progress and perspective in solution-processed interfacial materials for efficient and stable polymer and organometal perovskite solar cells. Energy Environ Sci, 2015, 8: 1160-1189

9 Zhao X, Tao L, Li H, et al. Efficient planar perovskite solar cells with improved fill factor via interface engineering with graphene. Nano Lett, 2018, 18: 2442-2449

10 Wen X, Wu J, Gao D, et al. Interfacial engineering with amino-functionalized graphene for efficient perovskite solar cells. J Mater Chem A, 2016, 4: $13482-13487$

11 Cai Y, Zhang Z, Zhou Y, et al. Enhancing the efficiency of low-temperature planar perovskite solar cells by modifying the interface between perovskite and hole transport layer with polymers. Electrochim Acta, 2018, 261: 445-453

12 Taherianfard H, Kim G W, Ebadi F, et al. Perovskite/Hole transport layer interface improvement by solvent engineering of spiro-OMeTAD precursor solution. ACS Appl Mater Interfaces, 2019, 11: 44802-44810

13 Hwang I, Jeong I, Lee J, et al. Enhancing stability of perovskite solar cells to moisture by the facile hydrophobic passivation. ACS Appl Mater Interfaces, 2015, 7: 17330-17336

14 Peng J, Wu Y, Ye W, et al. Interface passivation using ultrathin polymer-fullerene films for high-efficiency perovskite solar cells with negligible hysteresis. Energy Environ Sci, 2017, 10: 1792-1800

15 Zhu Y, Murali S, Cai W, et al. Graphene and graphene oxide: Synthesis, properties, and applications. Adv Mater, 2010, 22: 3906-3924

16 Loh K P, Bao Q, Eda G, et al. Graphene oxide as a chemically tunable platform for optical applications. Nat Chem, 2010, 2: 1015-1024

17 Chen D, Feng H, Li J. Graphene oxide: Preparation, functionalization, and electrochemical applications. Chem Rev, 2012, 112: 6027-6053

18 Sun X, Lin T, Song Q, et al. Improved performance of hole-transporting layer-free perovskite solar cells by using graphene oxide sheets as the nucleation centers. RSC Adv, 2017, 7: 45320-45326

19 Rafique S, Roslan N A, Abdullah S M, et al. UV-ozone treated graphene oxide/PEDOT:PSS bilayer as a novel hole transport layer in highly efficient and stable organic solar cells. Org Electron, 2019, 66: 32-42

20 Li W, Dong H, Guo X, et al. Graphene oxide as dual functional interface modifier for improving wettability and retarding recombination in hybrid perovskite solar cells. J Mater Chem A, 2014, 2: 20105-20111

21 Mann D S, Seo Y H, Kwon S N, et al. Efficient and stable planar perovskite solar cells with a PEDOT:PSS/SrGO hole interfacial layer. J Alloys Compd, 2020, 812: 152091

22 Lee D Y, Na S I, Kim S S. Graphene oxide/PEDOT:PSS composite hole transport layer for efficient and stable planar heterojunction perovskite solar cells. Nanoscale, 2016, 8: 1513-1522

23 Du B B, Zhao D W, Hou Z Z, et al. Interfacial modification for perovskite solar cells using a novel fused-ring electron acceptor (in Chinese). Chin Sci Bull, 2019, 64: 1887-1895 [杜斌斌, 赵大伟, 侯志灼, 等. 新型稠环电子受体的界面修饰对钲钛矿太阳能电池性能的影响. 科学通报, 2019, 64: 1887-1895]

24 Zhou Y Q, Wu B S, Lin G H, et al. Interfacing pristine $\mathrm{C}_{60}$ onto $\mathrm{TiO}_{2}$ for viable flexibility in perovskite solar cells by a low-temperature all-solution process. Adv Energ Mater, 2018, 8: 1800399

25 Yun D Q, Feng W, Wu H C, et al. Optical properties of conjugated polymer-ZnSe nanocrystal nanocomposites. Chin Phys B, 2010, 19: 017304

26 Yang Q D, Li J, Cheng Y, et al. Graphene oxide as an efficient hole-transporting material for high-performance perovskite solar cells with enhanced stability. J Mater Chem A, 2017, 5: 9852-9858

27 Yang C, Hu Z, Gao C, et al. Elimination of light-soaking effect in hysteresis-free perovskite solar cells by interfacial modification. J Phys Chem C, 2020, 124: 1851-1860

28 Fang Y, Huang J. Resolving weak light of sub-picowatt per square centimeter by hybrid perovskite photodetectors enabled by noise reduction. Adv Mater, 2015, 27: 2804-2810

29 Yang D, Yang R, Zhang J, et al. High efficiency flexible perovskite solar cells using superior low temperature $\mathrm{TiO}_{2}$. Energy Environ Sci, 2015, 8: 3208-3214

30 Ghosh A, Chaudhary D K, Mandal A, et al. Core/Shell nanocrystal tailored carrier dynamics in hysteresisless perovskite solar cells with $20 \%$ efficiency and long operational stability. J Phys Chem Lett, 2020, 11: 591-600

31 Qu J R, Zheng J B, Wu G R, et al. Bulk heterojunction photovoltaic devices based on a poly(2-methoxy, 5-octoxy)-1,4-phenylenevinylene-single walled carbon nanotube-ZnSe quantum dots active layer. Chin Phys Lett, 2013, 30: 107801 


\title{
Improved performance of perovskite solar cells using conju- gated polymer-graphene oxide as the passivation material
}

\author{
Dawei Zhao ${ }^{1}$, Ming Li $^{1}$, Shijie Dai ${ }^{1}$, Dichun Chen $^{2}$, Lingling Zheng ${ }^{1 *} \&$ Daqin Yun ${ }^{1 *}$ \\ ${ }^{1}$ School of Energy, Xiamen University, Xiamen 361105, China; \\ ${ }^{2}$ Xiamen Branch of Luoyang Ship Material Research Institute, Xiamen 361006, China \\ * Corresponding authors, E-mail: 1lzheng@xmu.edu.cn; dqyun@xmu.edu.cn
}

Organic-inorganic hybrid perovskite solar cells (PSCs) have achieved power conversion efficiency (PCE) from 3.8\% to $25.2 \%$ in recent years. However, the charge transport ability of the transporting layers and the quality of crystalline films limit further development of PSCs. To fabricate highly efficient PSCs, effective charge transport to electrodes through transporting layers is a necessary requirement. Suitable interface engineering is very critical because it can not only benefit the charge extraction and transport, but also effectively passivate the traps on the surface and grain boundary of the perovskite. It has been shown that the passivation layer for the perovskite plays a vital role in the performance of PSCs. The close fit between the charge transport layer and the perovskite layer is required to reduce the interfacial recombination and accelerate the carrier extraction and collection. Besides, the appropriate passivation layer has a potential impact on the crystallization and the morphology of the perovskite film. To achieve high-performance devices, it is crucial to design an effective passivation layer with appropriate nanomaterials.

In this work, we synthesized poly[(2-methoxy,5-octoxy)1,4-phenylenevinylene] (MOPPV) on few-layer graphene oxide (GO) by in situ polymerization at room temperature. MOPPV-GO can fully combine the advantages of the two materials. The novel nanocomposite MOPPV-GO is used as the ultra-thin passivation layer of PSCs, of which the structure is ITO/ $\mathrm{TiO}_{2} /\left(\mathrm{FAPbI}_{3}\right)_{x}\left(\mathrm{MAPbCl}_{3}\right)_{1-x} / \mathrm{MOPPV}-\mathrm{GO} /$ spiro-OMeTAD/Ag. Since the surface morphology of the perovskite layer would affect the performance of devices significantly, the perovskite films with and without the passivation layer by atomic force microscopy is found that the MOPPV-GO can facilitate the growth of perovskite crystal with larger grains and enhance the quality of perovskite films. The root mean square roughness values of the perovskite films with and without MOPPV-GO were evaluated to be 19.87 and $25.85 \mathrm{~nm}$, justifying the improvement of the surface flatness of the perovskite film with the decoration of MOPPV-GO, which would enhance the contact and carrier transport between the hole transport layer and the perovskite layer. As a result, the PSCs with MOPPV-GO exhibited considerably low hysteresis indices $(0.02)$ and showed a short circuit current density of $23.54 \mathrm{~mA} \mathrm{~cm}^{-1}$, an open circuit voltage of $1.09 \mathrm{~V}$, and a fill factor of $76.46 \%$, corresponding to a high power conversion efficiency of $19.73 \%$. By contrast, the control PSCs without MOPPV-GO showed a high hysteresis index of 0.18 , with a poor power conversion efficiency of $16.42 \%$. Meanwhile, it is shown that the EQE curve of MOPPV-GO modified PSC is higher than that of unmodified devices, which is consistent with the experimental results of $J-V$ curve. The steady-state power output of various devices in ambient conditions under continuous AM 1.5G illumination was tested, which shows excellent stability of the PSC with MOPPV-GO during the period of $1000 \mathrm{~s}$, indicating the positive contribution of MOPPV-GO interlayer to the stability. This work could provide a new idea for the synthesis and application of graphene-based materials in solar cells.

passivation materials, MOPPV-GO, perovskite solar cells, interfacial modification

doi: 10.1360/TB-2020-0297 